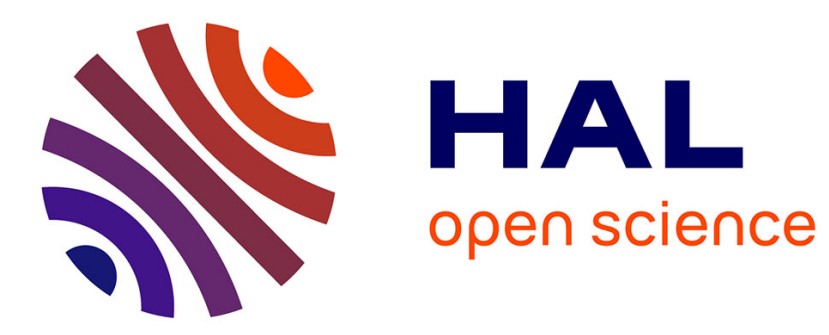

\title{
Causes, presentation and outcome of lesional adult-onset mediotemporal lobe epilepsy
}

Bettina M Soeder, Ulrike Gleissner, Horst Urbach, Hans Clusmann, Christian E Elger, Angela Vincent, Christian G Bien

\section{- To cite this version:}

Bettina M Soeder, Ulrike Gleissner, Horst Urbach, Hans Clusmann, Christian E Elger, et al.. Causes, presentation and outcome of lesional adult-onset mediotemporal lobe epilepsy. Journal of Neurology, Neurosurgery and Psychiatry, 2009, 80 (8), pp.894. 10.1136/jnnp.2008.165860 . hal-00552737

\section{HAL Id: hal-00552737 \\ https://hal.science/hal-00552737}

Submitted on 6 Jan 2011

HAL is a multi-disciplinary open access archive for the deposit and dissemination of scientific research documents, whether they are published or not. The documents may come from teaching and research institutions in France or abroad, or from public or private research centers.
L'archive ouverte pluridisciplinaire HAL, est destinée au dépôt et à la diffusion de documents scientifiques de niveau recherche, publiés ou non, émanant des établissements d'enseignement et de recherche français ou étrangers, des laboratoires publics ou privés. 


\section{Causes, presentation and outcome of lesional adult-onset mediotemporal lobe epilepsy}

Bettina M. Soeder ${ }^{1}$, Ulrike Gleissner ${ }^{1}$, Horst Urbach $^{2}$, Hans Clusmann ${ }^{3}$, Christian E. Elger ${ }^{1}$, Angela Vincent ${ }^{4}$, Christian G. Bien ${ }^{1}$

University of Bonn, Bonn, Germany, Depts. of ${ }^{1}$ Epileptology, ${ }^{2}$ Radiology/Neuroradiology, and ${ }^{3}$ Neurosurgery. ${ }^{4}$ Neurosciences Group, Weatherall Institute of Molecular Medicine, University of Oxford, John Radcliffe Hospital, Oxford, UK

\section{Corresponding author:}

Christian G. Bien, MD

University of Bonn

Department of Epileptology

Sigmund-Freud-Str.25

53105 Bonn

Phone: +49-228-287-15712

Fax: +49-228-287-19351

E-mail: christian.bien@ukb.uni-bonn.de

\section{Word and character counts, numbers of tables, figures and references:}

Title

Running title

Abstract

Text

No. of tables

No. of figures

No. of references

No. of supplemental tables
84 characters including spaces

33 characters including spaces

248 words

3126 words

Keywords: mediotemporal lobe epilepsy - adults - limbic encephalitis - amygdala - MRI antibodies 


\begin{abstract}
Purpose: Mediotemporal lobe (MTL) epilepsy (MTLE) is particularly frequent among human localization-related epilepsies. MTLE usually starts before adulthood and is most frequently associated with hippocampal sclerosis (HS). Here, aetiologies, disease courses, and outcomes of adult-onset MTLE patients treated at this tertiary epilepsy centre are studied.

Methods: We collected all patients studied between 01/1999-12/2005 fulfilling the following criteria: (1) MTLE manifestation at age > 20 years; (2) time between disease manifestation and assessment $\leq 6$ years; (3) MTL lesion on brain MRI; (4) neuropsychological test battery applied. We classified the diagnoses and documented the paraclinical data, neuropsychological performances, and seizure and memory outcomes.

Results: Diagnoses in the 84 patients (mean age 42 years at MTLE onset) were: limbic encephalitis (LE), $\mathrm{N}=23$ (27\%); HS (unrelated to inflammation), N=18 (22\%); tumours I/II ${ }^{\circ}$, $\mathrm{N}=12$ (14\%); amygdala lesions (increased volume and T2/FLAIR signal), N=11 (13\%); other, $\mathrm{N}=20$ (24\%). Visible MTL affection was frequently bilateral in LE (57\%) and HS (22\%) patients. These groups also showed the poorest memory performance. Patients with amygdala lesions were the oldest ones (mean age 52 years); their lesions are in part immunemediated and in part probably dysplastic. Treatment-dependent seizure outcomes were similar to published data without restriction to adult onset-cases. Under conservative therapy, memory performance remained stable in HS patients but improved in a proportion of LE patients.
\end{abstract}


Conclusions: The data suggest that LE is a common and previously underestimated cause of

MTLE in this age group. Its prognosis is variable. Amygdala lesions, too, -are in part encephalitic in nature. 


\section{INTRODUCTION}

Mediotemporal lobe (MTL) epilepsy (MTLE) is particularly frequent among human localization-related epilepsies, and most cases start in childhood or adolescence. In autopsy and epilepsy surgery series, the most frequently observed morphological substrate of the epileptogenic area is hippocampal sclerosis (HS). ${ }^{1-6}$ However, there are few data on the causes of adult-onset MTLEs. Epidemiological studies in adult-onset epilepsies in general suggested vascular, traumatic, tumoural, and (in individuals $>64$ years of age) neurodegenerative aetiologies. ${ }^{7 ; 8}$ These studies, however, did not specifically address the subgroup of MTLE. Furthermore, such studies cover large numbers of patients and are not designed to detect subtle disease processes requiring extensive in-depth investigations. Therefore, in the present study, we assessed all patients who developed adult-onset MTLE with MTL lesions on high-resolution brain MRI over a seven year period from our tertiary epilepsy centre. It extends our previous study, which revealed that limbic encephalitis (LE) was a frequent underlying substrate of lesional adult-onset MTLE-HS. ${ }^{9}$ It also identifies a patient group with amygdala lesions of in part encephalitic and in part probably dysplastic origin.

\section{Patients AND Methods}

\section{Inclusion criteria}

We selected all patients treated at Department of Epileptology of the University of Bonn between January 1999 and December 2005 who fulfilled the following criteria:

(1) Manifestation of epilepsy with seizures compatible with an MTL origin, at the age of 
$\geq 20$ years.

(2) First comprehensive assessment, including brain MRI, at this centre within six years of MTLE onset (this limit was chosen to have a high chance of obtaining detailed data and diagnostic material of the patients).

(3) At presentation to this centre, MRI diagnosis of an MTL lesion by an experienced neuroradiologist (H.U.). HS is regarded as a lesion in this study.

(4) At presentation to this centre, assessment of cognitive performance by a neuropsychological test battery assessing verbal and visual memory, and attention functions.

\section{Data collection from the time point of initial assessment}

We retrospectively assessed the following data from the patients' records: date of epilepsy onset, history of potential causative antecedent events ("initial precipitating injuries",

IPIs ${ }^{10 ; 11}$ ), monthly seizure frequency (all types of epileptic seizures), and the drug therapy including antiepileptic drugs (AED). The MRI interpretation based on images obtained by a dedicated epilepsy protocol ${ }^{12}$ was noted (and re-checked with an experienced neuroradiologist [H.U.] if doubtful). Results of standard CSF analyses and tests for autoantibodies known to be associated with LE were noted. Sera were tested by immuno-dotblotting for $\mathrm{Hu}$, Yo, Ri, CV2/CRMP5, amphiphysin, Ma1 and Ma2 antibodies on a commercially available blotting test ${ }^{13}$ plus by indirect immunohistochemistry, both performed by the Department of Clinical Chemistry of the University of Cologne, Cologne, Germany according to internationally accepted practice. ${ }^{14}$ Sera were also tested for VGKC antibodies by radioimmunoprecipitation performed by A.V. with values $>100 \mathrm{pmol} / \mathrm{l}$ regarded as positive. ${ }^{15 ; 16}$ 
Neuropsychological performance at the initial visit was assessed with the following tests:

- The Verbal Learning and Memory Test (VLMT - a German adaptation of the Rey Auditory Verbal Learning Test ${ }^{17}$ ) assessed the following parameters for verbal memory: learning capacity (sum of recalled words in five consecutive learning trials), loss in delayed recall (recalled words after a time delay of thirty minutes minus recalled words in the fifth trial), and recognition (correctly recognized words minus false alarms).

- The Diagnostikum für Cerebralschädigung, revised version ${ }^{18}$ assessed visual memory: nine abstract designs have to be reconstructed by use of five wooden sticks, the parameter of interest was the learning capacity (sum of reconstructed designs across five learning trials).

- Attentional speed was assessed with the $\mathrm{d} 2$ test, ${ }^{19}$ a visual cancellation task; and the trail making test (TMT), parts A and B for the assessment of attention functions. ${ }^{20}$ Parameters of interest were the total score (correct cancellations minus failures) for the $\mathrm{d} 2$ test, and the time in seconds for the TMT.

All parameters were transformed into standardized values or percentiles according to the norms provided in the manuals.

\section{Diagnostic classification}

Where available, histopathology was used to determine the precise diagnoses of tumors, ${ }^{21}$ $\mathrm{HS}^{22}$ and other well-defined lesions like cavernomas. If no surgical brain specimen was available, diagnoses were made by MRI interpretation according to established criteria. ${ }^{12 ; 23}$ 
"Definite LE" was diagnosed according to the PNS Euronetwork criteria, ${ }^{24}$ including VGKC antibodies as diagnostic markers. "Possible LE" was diagnosed using criteria of serial MRI (evolution from mediotemporal signal increase and swelling to atrophy over several months) as described earlier. ${ }^{9 ; 25}$ See also Figure 1. Posttraumatic epilepsy was diagnosed if there was a history of severe brain injury plus mediotemporal postcontusional findings on histopathology or characteristic posttraumatic MRI lesions on the appropriate sequences including $\mathrm{T} 2 *{ }^{26}$ Other, less common diagnoses were made in accordance to established standards, too.

\section{Treatment categorization}

The treatment administered after the first visit to this centre was categorized as follows:

- "Surgery": epilepsy surgery after comprehensive presurgical assessment following commonly accepted principles ${ }^{27}$ with subsequent ongoing administration of AEDs for at least one year after the operation.

- "AED only": anticonvulsive pharmacotherapy only.

- “AED + immunotherapy": anticonvulsive pharmacotherapy plus immunointerventions (as detailed in the results section).

\section{Outcome assessment}

Seizure outcome. For the most recent follow-up visit, the interval to surgery or to the first visit (as applicable) was noted. A minimum follow-up of six months was required; otherwise "no follow-up" was noted. Seizure outcome was assessed in a dichotomous way: A patient was either "seizure-free" (if the patient was free of all types of epileptic manifestations 
including auras for at least the previous year or the total available follow-up if this was $<1$ year) or "not seizure-free".

Neuropsychological outcome. Neuropsychological re-tests after at least 6 months were evaluated as available in the conservatively treated patients (because it was not intended here to assess the effect of tissue removal by resective epilepsy surgery). Significance of individual changes in verbal memory performance (domains verbal learning, loss in delayed recall, and recognition) was evaluated using the categories "gain", "stable" or "loss". This was done using reliable change indices (RCIs) according to previous proposals. ${ }^{28} \mathrm{RCI}$ provides an index of significant and reliable alteration in test performance, a change that cannot be attributed to common sources of measurement error inherent in test-/re-test designs (e.g., practice effects, regression to the mean). Individual changes were classified as being worse or improved if they exceeded the $90 \%$ confidence intervals for the before and after difference scores derived from 81 healthy controls (mean age 50 years, SD 12 years, range 16-68 years, 22 male) who had been tested twice (mean retest interval 5.3 months, SD 1.7).

\section{Statistical evaluation}

Because of the limited group sizes, non-parametric tests were performed for statistical comparisons ( $\mathrm{chi}^{2}$ test and Kruskal-Wallis-test, as appropriate). $\mathrm{P}$ values $<0.05$ were considered significant. 


\section{RESULTS}

Eighty-four patients with adult-onset MRI-positive MTLE fulfilled the inclusion criteria. Their clinical and paraclinical data and sub-division in diagnosis groups are given in the Table. Only thirteen $(10 \%)$ were $\geq 60$ years, and no more than seven patients $(8 \%)$ were $\geq 64$ years. For serum antibody and CSF findings, see Supplemental table 1, for the neuropsychological performance, see Supplemental table 2. .

Limbic encephalitis $(N=23,27 \%)$. Six patients proved to have paraneoplastic definite LE. The detected tumours were: small cell lung cancer $(\mathrm{N}=2)$, testicular cancer $(\mathrm{N}=1)$, uterine leiomyosarcoma $(\mathrm{N}=1)$, rectal carcinoma $(\mathrm{N}=1)$; undetected in the presence of $\mathrm{Hu}$ antibodies $(\mathrm{N}=1)$. Three of these patients had onconeural antibodies $(\mathrm{Hu}, \mathrm{N}=2 ; \mathrm{Ma} 2, \mathrm{~N}=1)$. Five patients had non-paraneoplastic definite LE associated with VGKC antibodies. Twelve patients were classified as having possible LE on the basis of evolving mediotemporal MRI features ${ }^{9 ; 25}$ in the absence of detected auto-antibodies or a tumour. A typical example is given in Figure 2 , C-E. At the initial visit to this centre after a median of 7.4 months into the disease (range: 5 days-5.6 years), 20 of the 23 patients already had hippocampal atrophy (and had therefore been included in our previous study ${ }^{9}$ ). Disease onset was indicated by manifestation of recurrent seizures in all patients (often accompanied by memory decline) apart from one who had memory impairment only for 2.4 years before epilepsy onset. On formal neuropsychological assessment at initial presentation to this centre, memory performance was poor. At least half of the patients performed below one standard deviation of controls in the different verbal memory domains.. 
Hippocampal sclerosis not related to $L E(N=18$ - i.e., $22 \%$ of the total cohort). Eleven of the patients in this group had HS which was preceded by an IPI (childhood meningitis, $\mathrm{N}=1$; febrile seizures, $\mathrm{N}=1$; brain trauma, $\mathrm{N}=2$; status epilepticus, $\mathrm{N}=3$; of note, patients with HS evolving from LE were included in the LE subgroup, described the previous paragraph) or in the context of another brain lesion (“dual pathology": old ipsilateral posterior cerebral artery infarctions, $\mathrm{N}=2$; ipsilateral parietal porencephalic cyst, $\mathrm{N}=1$, neurofibromatosis type $\mathrm{I}$, $\mathrm{N}=1$ ). In the remaining seven patients, no antecedent event or dual pathology could be identified. All patients in this group were included in our previous study on adult-onset MTLE with HS. ${ }^{9}$ The MRI appearance of these HS by MRI and neuropathology (if surgery was done) was indistinguishable from that of patients with disease onset before adulthood (see Figure 2 A). Four of the 18 patients had bilateral HS (22\%). Memory performance in the HS patients at first assessment was poor: More than half of the patients performed below one standard deviation of controls in each of the verbal and non-verbal memory domains.

Tumours $\mathrm{WHO} \mathrm{I}^{\circ} / \mathrm{II}^{\circ}(\mathrm{N}=12,14 \%)$. In seven patients, the diagnosis was made by histopathological study of brain tissue obtained at epilepsy surgery. The detailed diagnoses were: dysembryoplastic neuroepithelial tumor (DNT) WHO I $(\mathrm{N}=2$; an example is given in Figure 2, B $)$, ganglioglioma $\mathrm{I}^{\circ}(\mathrm{N}=4)$, ganglioglioma $\mathrm{II}^{\circ}(\mathrm{N}=1)$. In the remaining five cases, MRI suggested low grade tumours $\left(\mathrm{DNT} \mathrm{I}^{\circ}\right.$, ganglioglioma $\mathrm{I}^{\circ}$, astrocytoma $\mathrm{II}^{\circ}$ ); these patients did not undergo epilepsy surgery at this stage because they either were not yet pharmacoresistant or refused surgical treatment. Left-sided temporal damage is often associated with verbal memory deficits. However, even though in this group the left side was more often affected than the right one (9:3), mean verbal memory performance of this group 
was within one standard deviation of normal controls, i.e., within the average range; on an individual level, too, the performance was clearly better than in the previous two groups.

Amygdala lesions $(N=11,13 \%)$. Eleven patients presented with homogenously increased amygdala volumes and signal intensities on FLAIR or T2 MRI sequences. In four cases, the hippocampal head appeared to be involved in the same process. None of these lesions showed contrast enhancement. The eleven patients in this group had the oldest mean age at epilepsy onset of all groups (52 years). Neuropsychological performance at initial assessment was better than in the HS and LE patients and more like that of the patients with tumours $\mathrm{I} / \mathrm{II}^{\circ}$ even though, again, the left side was more often affected than the right one $(8: 2$; one patient showed bilateral affection). Three patients underwent MTL resections. Two patients had a follow-up, and both were seizure-free.

CSF findings, histopathology or a temporary evolution of the amygdala lesions (regression of MRI-T2/FLAIR signal increases over time, see Figure 2, F-H) suggested a chronicinflammatory origin in five patients (median age at onset 66 years, range 45-71 years; only one patient $<50$ years). In the remaining six patients, CSF findings, non-encephalitic histopathology or long-term stability amygdalar MRI lesions stable [see Figure 2, I-L]. These patients were younger (median 46 years, range 23-61; only two patients $>50$ years) than their encephalitic counterparts. It is likely that some form of dysplastic lesion underlie the MRI changes. Individual data are given in Supplemental table $3 .$. 
Others $(N=20,24 \%)$. In these remaining patients, the following conditions underlying MTLE were diagnosed: Tumours $\mathrm{III}^{\circ} / \mathrm{IV}^{\circ}(\mathrm{N}=6)$, posttraumatic lesions $(\mathrm{N}=5)$, cavernoma $(\mathrm{N}=3)$, chronic herpes simplex encephalitis $(\mathrm{N}=2)$, cerebral amyloid angiopathy with inflammation ${ }^{29}$ $(\mathrm{N}=1)$, and not further specified mediotemporal MRI lesions $(\mathrm{N}=3)$. In the patients with tumours III/IV ${ }^{\circ}$, the diagnosis was made histopathologically. Two constellations occurred: either, surgery was performed when signs of malignancy were unexpectedly found during presurgical work-up (resulting in a resection for neurosurgical indication, $\mathrm{N}=2$ ); or, a $\mathrm{I}^{\circ} / \mathrm{II}^{\circ}$ tumour was suspected during work-up for epilepsy, and only histopathology revealed the diagnosis of a grade $\mathrm{III}^{\circ} / \mathrm{IV}^{\circ}$ tumour $(\mathrm{N}=4)$. The neuropathological diagnoses were: glioblastoma multiforme $(\mathrm{N}=1)$, anaplastic oligodendroglioma $(\mathrm{N}=1)$, anaplastic astrocytoma $(\mathrm{N}=3)$, and anaplastic oligoastrocytoma $(\mathrm{N}=1)$.

\section{Outcome}

In the following, outcome data are analyzed only for the four main groups delineated above (64 patients). Due to the retrospective nature of this study, outcome data ware available only for part of the patients as indicated in the following paragraphs.

Seizure-free outcome. Data were available for 43/64 patients: for 18/19 surgically treated patients, for 9/25 AED only-treated patients and for 16/20 AED + immunotherapy patients. Four types of immunotherapy were applied in the patients with follow-up data available: (1) Monthly pulses of 3-5 g of intravenous methylprednisolone (i.v. MP), applied over a period of 1-24 months ( $\mathrm{N}=10)$; (2) i.v. MP as before over 4 or 8 months, followed by oral prednisone, tapered from $100 \mathrm{mg} /$ day to $<7.5 \mathrm{mg}$, total application duration 2.5 or 36 months 
$(\mathrm{N}=2)$; (3) oral prednisone, dosing in (2), administered over 13-78 months ( $\mathrm{N}=4)$; (4) one pulse of i.v. MP as in (1) followed by 15 doses of intravenous immunoglobulins at $0.4 \mathrm{~g} / \mathrm{kg}$ body weight $(\mathrm{N}=1)$. There were no serious adverse events. After a median follow-up of 1.9 years (range 0.5-6.0 years), 23/43 patients were seizure-free (53\%). Patients with benign tumours had a very favourable seizure-free outcome (6/7) after resective epilepsy surgery. Four out of seven surgically treated HS patients became seizure-free, but only $1 / 5$ conservatively treated HS patients. LE patients achieved an intermediate seizure-free outcome rate under conservative treatment of 5/13 (4/11 patients became seizure-free under AED + immunotherapy, two of them had been VGKC antibody positive and two antibody negative). For further details, see Supplemental table 4.

Neuropsychological outcome. Verbal memory outcome data were available from 15/25 conservatively treated patients in the four main groups (for the purposes of this study, neuropsychological outcome data of the operated patients were not considered as explained in the Methods section): 3/25 AED-only and 12/20 AED + immunotherapy patients; in the latter, treatment types according to the categories given in previous paragraph were as follows: (1) $\mathrm{N}=6$; (2) $\mathrm{N}=1$; (3) $\mathrm{N}=4$; (4) $\mathrm{N}=1$. Patients were re-tested after a minimum period of six months (median follow-up: 15 months, range: 6-44 months). Whereas the four HS patients had a stable verbal memory performance, there was an improvement in one to four (depending on the test domain) out of eight LE patients treated by AED + immunotherapy. For details, see Supplemental table 5. 


\section{DISCUSSION}

We studied causes, presentation and outcome of an adult-onset MTLE cohort with lesional brain MRI ( $\geq 20$ years) collected retrospectively at our tertiary epilepsy referral centre. The largest group (more than one quarter) is made up by patients with LE as defined by the criteria for paraneoplastic neurological syndromes, ${ }^{24}$ by VGKC antibodies ${ }^{16}$ or by evolutionary mediotemporal MRI changes. ${ }^{9 ; 25}$

The cohort studied here was younger than that of classical studies in the elderly $(\geq 60$ or $\geq 65$ years at onset), $8 ; 30 ; 31$ and thus represented the depressed part in the tub-shaped incidence curve of epilepsies. ${ }^{8 ; 32}$ Such patients have not been studied extensively before. The cohort is homogenous in terms of localization of the epileptogenic area because all have MTLE. A potential selection or referral bias must, however, be taken into account since the patients were recruited in a tertiary epilepsy centre that is likely to take care of highly particular patients.

LE has a strong tendency to bilateral mediotemporal involvement as evident by MRI findings and by the poor memory performance indicating extensive MTL dysfunction. The second largest group is made up by cases of HS (unrelated to LE) accounting for about one fifth of cases. A considerable group (13\% of the total cohort, which is almost the same as the proportion with tumours $\mathrm{I}^{\circ} / \mathrm{II}^{\circ}$ ) has amygdala lesions. This is a spectrum of causes clearly different from the typical childhood-adolescent onset MTLE among which HS cases predominate. It also differs from that of adult-onset epilepsy cohorts studied for epidemiological purposes. In the careful Iceland epilepsy incidence study, one subgroup consisted of patients aged 15 to 64 years (the age range in this subgroup largely resembles 
ours, in which the $\geq 64$ year old patients were a minority). In this Iceland subgroup, a cause underlying the unprovoked seizures was identified in only $31 \%{ }^{8}$ The comparability of these data to ours, however, is limited for two reasons: Firstly, in the Iceland study not only MTL epilepsies were included. Secondly, only $85 \%$ of all patients underwent structural neuroimaging, and this was in an unspecified proportion only done by a CT scan. Therefore, more subtle lesions like HS, LE or amygdala lesions may have been missed in part of the patients.

\section{Amygdala lesions}

The existence of MTLE patients with amygdala lesions characterized by increased volume and T2/FLAIR signal has been suggested by a previous report. ${ }^{33}$ Our observations suggest underlying encephalitis in about half of the patients. The other half of amygdala lesion cases in our sample - younger than the other one - seem to have a stable underlying pathology without features suggestive of encephalitis. It is likely that they have dysplastic or benign tumoural lesions as assumed by the authors of a previous study. ${ }^{33}$ Future research will be required to disentangle the histopathological abnormalities in those amygdala lesions. It may be speculated that the progressively atrophic encephalitic amygdala lesions may end up as amygdala sclerosis. ${ }^{34 ; 35}$ In line with this hypothesis is the observation that MTLE patients with amygdala atrophy on MRI had more frequently a history of encephalitis than MTLE patients with normal amygdala volumes. ${ }^{36}$

\section{Seizure outcomes related to aetiology and treatment}

Seizure-free outcome rates of surgically treated patients due to benign tumours (86\%) or HS (57\%) were as high as from those in published series without restriction to cases with adult- 
onset epilepsies. ${ }^{37-40}$ The low proportion of conservatively treated HS patients becoming seizure-free (20\%) is also well comparable to the seizure outcome in AED treated MTLE-HS patients in general. ${ }^{41}$ The seizure-free outcome rate in conservatively treated LE patients was intermediate (38\%). A beneficial role of immunotherapy in patients with LE may emerge in the near future. The present uncontrolled, retrospective study with non-uniformly treated patients can, however, not provide treatment efficacy data.

\section{Memory outcomes}

Whereas the verbal memory performance of patients with non LE-related HS remained stable over time, a proportion of patients in the LE group undergoing AED + immunotherapy improved. This underlines that LE is no static condition, and affected patients' cognitive performance may benefit from immunotherapy.

\section{Management of patients with adult-onset MTLE}

In patients with adult-onset MTLE, an immune-mediated condition should always be considered unless another well-defined type of disorder (like a tumour) can be identified. In cases with MTL lesions suspicious of representing encephalitis, tumour search, tests for onconeural and VGKC antibodies and follow-up MRIs are suggested to confirm and to refine the preliminary diagnosis. 


\section{ACKNOWLEDGEMENTS}

The authors thank Prof. Dr. Albert J. Becker, University of Bonn, Dept. of Neuropathology, for generously providing paraffin-embedded brain specimens, Mrs. Hannelore Storma and Mr. Mathias Theek for expert assistance with the artwork, Mrs. Claudia Ullmann for excellent technical assistance with histological stainings, and Ms. Linda Clover for the VGKC antibody testing.

$\mathrm{AV}$ and her department receive royalties and payments for antibody tests. The remaining authors have no conflicts of interest.

The Corresponding Author has the right to grant on behalf of all authors and does grant on behalf of all authors, an exclusive licence (or non exclusive for government employees) on a worldwide basis to the BMJ Publishing Group Ltd and its licencees, to permit this article (if accepted) to be published in JNNP and any other BMJ Group products and to exploit all subsidiary rights, as set out in our licence (http://jnnp.bmjjournals.com//ifora/licence.pdf) 


\section{REFERENCES}

1. Spielmeyer W. Die Pathogenese des epileptischen Krampfes. Histopathologischer Teil. Z.ges.Neurol.Psychiat. 1927;109:501-20.

2. Falconer MA, Serafetinides EA, Corsellis JAN. Etiology and pathogenesis of temporal lobe epilepsy. Arch Neurol 1964;10:233-48.

3. Margerison JH, Corsellis JA. Epilepsy and the temporal lobes. A clinical, electroencephalographic and neuropathological study of the brain in epilepsy, with particular reference to the temporal lobes. Brain 1966;89:499-530.

4. Bruton CJ. The neuropathology of temporal lobe epilepsy. Oxford: Oxford University Press, 1988.

5. Wolf HK, Campos MG, Zentner J, Hufnagel A, Schramm J, Elger CE, Wiestler OD. Surgical pathology of temporal lobe epilepsy. Experience with 216 cases. J.Neuropathol.Exp.Neurol. 1993;52:499-506.

6. Peiffer J. Neuronale Schäden durch Epilepsien. Klinisch-neuropathologische Korrelationsversuche zur Frage der Krampfschäden beim Menschen. Stuttgart/New York: Georg Thieme Verlag, 1993.

7. Õun A, Haldre S, Mägi M. Incidence of adult epilepsy in Estonia. Acta Neurol Scand. 2003;108:245-51. 
8. Olafsson E, Ludvigsson P, Gudmundsson G, Hesdorffer D, Kjartansson O, Hauser WA. Incidence of unprovoked seizures and epilepsy in Iceland and assessment of the epilepsy syndrome classification: a prospective study. Lancet Neurol 2005;4:627-34.

9. Bien CG, Urbach H, Schramm J, Soeder BM, Becker AJ, Voltz R, Vincent A, Elger CE. Limbic encephalitis as a precipitating event in adult-onset temporal lobe epilepsy. Neurology 2007;69:1236-44.

10. French JA, Williamson PD, Thadani VM, Darcey TM, Mattson RH, Spencer SS, Spencer DD. Characteristics of medial temporal lobe epilepsy: I. Results of history and physical examination. Ann.Neurol. 1993;34:774-80.

11. Mathern GW, Babb TL, Vickrey BG, Melendez M, Pretorius JK. The clinicalpathogenic mechanisms of hippocampal neuron loss and surgical outcomes in temporal lobe epilepsy. Brain 1995;118:105-18.

12. Urbach H. Imaging of the epilepsies. Eur Radiol 2005;15:494-500.

13. Ravo Diagnostika. Immuno-(Dot)-Blot for the detection of the paraneoplastic autoantibodies anti-HuD, anti-Yo, anti-Ri, anti-CV2 (CRMP5), anti-Amphiphysin, anti-Ma1 and anti-Ma2. http://www.ravo.de/en/Produkte/ravo_pns_blot_zu_immuno_verst.php; web page accessed 15-02-2009.

14. Moll JW, Antoine JC, Brashear HR, Delattre J, Drlicek M, Dropcho EJ, Giometto B, Graus F, Greenlee J, Honnorat J, et al. Guidelines on the detection of paraneoplastic anti-neuronal- specific antibodies: report from the Workshop to the Fourth Meeting of the International Society of Neuro-Immunology on paraneoplastic neurological 
disease, held October 22-23, 1994, in Rotterdam, The Netherlands. Neurology 1995;45:1937-41.

15. Hart IK, Waters C, Vincent A, Newland C, Beeson D, Pongs O, Morris C, NewsomDavis J. Autoantibodies detected to expressed $\mathrm{K}+$ channels are implicated in neuromyotonia. Ann.Neurol. 1997;41:238-46.

16. Vincent A, Buckley C, Schott JM, Baker I, Dewar BK, Detert N, Clover L, Parkinson A, Bien CG, Omer S, Lang B, Rossor MN, Palace J. Potassium channel antibodyassociated encephalopathy: a potentially immunotherapy-responsive form of limbic encephalitis. Brain 2004;127:701-12.

17. Helmstaedter C, Lendt M, Lux S. VLMT: Verbaler Lern- und Merkfähigkeitstest. Testhandbuch. Göttingen: Hogrefe, 2000.

18. Helmstaedter C, Pohl C, Elger CE. Eine modifizierte Version des Diagnostikums für Cerebralschäden (DCS) zur Diagnostik räumlich-visueller Gedächtnisdefizite bei Patienten mit Temporallappenepilepsie. In: Scheffner D, ed. Epilepsie 90. Reinbek: Einhorn-Presse 1991: 272-9.

19. Brickenkamp R. Test d2 Aufmerksamkeits-Belastungs-Test. Göttingen: Hogrefe, 1978.

20. Reitan RM. Trail Making Test. Manual for administration and scoring. South Tucson, AZ: Reitan Neuropsychology Laboratory, 1992.

21. Kleihues P, Cavenee WK. World Health Organization Classification of Tumours. Pathology \& Genetics. Tumours of the Nervous System. Lyon: IARC-Press, 2000. 
22. Wieser HG, ILAE commission on neurosurgery for epilepsy. ILAE commission report: Mesial temporal lobe epilepsy with hippocampal sclerosis. Epilepsia 2004;45:695-714.

23. Duncan JS. Imaging and epilepsy. Brain 1997;120:339-77.

24. Graus F, Delattre JY, Antoine JC, Dalmau J, Giometto B, Grisold W, Honnorat J, Sillevis Smitt P., Vedeler C, Verschuuren JJ, Vincent A, Voltz R. Recommended diagnostic criteria for paraneoplastic neurological syndromes. J Neurol Neurosurg Psychiatry 2004;75:1135-40.

25. Urbach H, Soeder BM, Jeub M, Klockgether T, Meyer B, Bien CG. Serial MRI of limbic encephalitis. Neuroradiology 2006;48:380-6.

26. Diaz-Arrastia R, Agostini MA, Frol AB, Mickey B, Fleckenstein J, Bigio E, Van Ness PC. Neurophysiologic and neuroradiologic features of intractable epilepsy after traumatic brain injury in adults. Arch Neurol 2000;57:1611-6.

27. Kral T, Clusmann H, Urbach J, Schramm J, Elger CE, Kurthen M, Grunwald T. Preoperative evaluation for epilepsy surgery (Bonn Algorithm). Zentralbl.Neurochir. 2002;63:106-10.

28. Hermann BP, Seidenberg M, Schoenfeld J, Peterson J, Leveroni C, Wyler AR. Empirical techniques for determining the reliability, magnitude, and pattern of neuropsychological change after epilepsy surgery. Epilepsia. 1996;37:942-50.

29. Eng JA, Frosch MP, Choi K, Rebeck GW, Greenberg SM. Clinical manifestations of cerebral amyloid angiopathy-related inflammation. Ann.Neurol 2004;55:250-6. 
30. Loiseau J, Loiseau P, Duche B, Guyot M, Dartigues JF, Aublet B. A survey of epileptic disorders in southwest France: seizures in elderly patients. Ann.Neurol. 1990;27:232-7.

31. Rowan AJ, Ramsay RE, Collins JF, Pryor F, Boardman KD, Uthman BM, Spitz M, Frederick T, Towne A, Carter GS, Marks W, Felicetta J, Tomyanovich ML. New onset geriatric epilepsy: a randomized study of gabapentin, lamotrigine, and carbamazepine. Neurology 2005;64:1868-73.

32. Hauser WA, Annegers JF, Kurland LT. Incidence of epilepsy and unprovoked seizures in Rochester, Minnesota: 1935-1984. Epilepsia 1993;34:453-68.

33. Bower SP, Vogrin SJ, Morris K, Cox I, Murphy M, Kilpatrick CJ, Cook MJ. Amygdala volumetry in "imaging-negative" temporal lobe epilepsy. $J$ Neurol.Neurosurg.Psychiatry 2003;74:1245-9.

34. Miller LA, McLachlan RS, Bouwer MS, Hudson LP, Munoz DG. Amygdalar sclerosis: preoperative indicators and outcome after temporal lobectomy. $J$ Neurol.Neurosurg.Psychiatry 1994;57:1099-105.

35. Zentner J, Wolf HK, Helmstaedter C, Grunwald T, Aliashkevich AF, Wiestler OD, Elger CE, Schramm J. Clinical relevance of amygdala sclerosis in temporal lobe epilepsy. J Neurosurg. 1999;91:59-67.

36. Tebartz van Elst L, Woermann FG, Lemieux L, Thompson PJ, Trimble MR. Affective aggression in patients with temporal lobe epilepsy: a quantitative MRI study of the amygdala. Brain. 2000;123:234-43. 
37. Zentner J, Hufnagel A, Wolf HK, Ostertun B, Behrens E, Campos MG, Elger CE, Wiestler OD, Schramm J. Surgical treatment of neoplasms associated with medically intractable epilepsy. Neurosurgery. 1997;41:378-86.

38. Choi JY, Chang JW, Park YG, Kim TS, Lee BI, Chung SS. A retrospective study of the clinical outcomes and significant variables in the surgical treatment of temporal lobe tumor associated with intractable seizures. Stereotact.Funct.Neurosurg. 2004;82:35-42.

39. Baldauf CM, Cukiert A, Argentoni M, Baise-Zung C, Forster CR, Mello VA, Burattini JA, Mariani PP, Camara RB, Seda L. Surgical outcome in patients with refractory epilepsy associated to MRI-defined unilateral mesial temporal sclerosis. Arq Neuropsiquiatr. 2006;64:363-8.

40. Lowe AJ, David E, Kilpatrick CJ, Matkovic Z, Cook MJ, Kaye A, O'Brien TJ. Epilepsy surgery for pathologically proven hippocampal sclerosis provides long-term seizure control and improved quality of life. Epilepsia 2004;45:237-42.

41. Semah F, Picot M-C, Adam C, Broglin D, Arzimanoglou A, Bazin B, Cavalcanti D, Baulac M. Is the underlying cause of epilepsy a major prognostic factor for recurrence? Neurology 1998;51:1256-62. 


\section{SUPPLEMENTAL MATERIAL}

Supplemental table E-1: Serum antibody and CSF findings

Supplemental table E-2: Cognitive performances of the patients from the main groups at initial presentation (means+standard deviations; in brackets nos. of patients with performance $<1$ standard deviation of normal controls; please note that not all patients were capable of completing all subtests)

Supplemental table E-3: Patients with etiologically undetermined amygdala lesions

Supplemental table E-4: Treatment-related seizure-free outcome for the four main diagnostic subgroups after a median of 1.9 years (range $0.5-6.0$ years)

Supplemental table E-5: Verbal memory outcome (change in performance) for the four main diagnostic subgroups related to treatment 


\section{FIGURE LEGENDS}

Figure 1: Diagnostic criteria for definite and possible limbic encephalitis.

Figure 2: Coronal brain T2/FLAIR images of lesional mediotemporal epilepsies with onset in adult life. Time data: disease duration ( $\mathrm{mo}=$ months, yrs=years).

(A) Right-sided hippocampal sclerosis. Male patient, age 49 years at epilepsy onset. (B) Right-sided dysembryoplastic neuroepithelial tumour WHO I ${ }^{\circ}$. Male patient, age 53 years at epilepsy onset. (C-E) Limbic encephalitis according to MRI criteria. Note the right-sided hippocampal signal and volume increase with subsequent transition into hippocampal atrophy with continuously increased signal (i.e., hippocampal sclerosis), male patient, age 66 years at epilepsy onset. (F-H) Left-sided amygdala lesion with regression over time. Female patient, age 45 years at epilepsy onset. (I-L) Right-sided stable amygdala lesion. Male patient, age 52 years at epilepsy onset. 
Table: Clinical and paraclinical features at initial presentation

\begin{tabular}{|c|c|c|c|c|c|c|c|}
\hline Groups & $\begin{array}{c}\mathrm{N} \\
\text { (female) }\end{array}$ & $\begin{array}{c}\% \\
\text { of all } 84 \\
\text { patients }\end{array}$ & $\begin{array}{c}\text { Median } \\
\text { age at } \\
\text { epilepsy } \\
\text { onset } \\
\text { (range) } \\
\text { [years] }\end{array}$ & $\begin{array}{l}\text { Median } \\
\text { time } \\
\text { since } \\
\text { seizure } \\
\text { onset } \\
\text { (range) } \\
\text { [years] }\end{array}$ & $\begin{array}{c}\text { Right/ } \\
\text { left/ } \\
\text { bilateral } \\
\text { affection } \\
\text { [accor- } \\
\text { ding to } \\
\text { MRI] }\end{array}$ & $\begin{array}{c}\text { Median } \\
\text { seizure } \\
\text { fre- } \\
\text { quency } \\
\text { (range) } \\
\text { [per } \\
\text { month] }\end{array}$ & $\begin{array}{c}\text { Median } \\
\text { no. of } \\
\text { AEDs } \\
\text { (range) }\end{array}$ \\
\hline $\begin{array}{l}\text { Whole } \\
\text { group }\end{array}$ & $\begin{array}{l}84 \\
(28)\end{array}$ & $100 \%$ & $\begin{array}{c}42 \\
(20-79)\end{array}$ & $\begin{array}{c}1.6 \\
(0.0-6.0)\end{array}$ & $25 / 35 / 24$ & $\begin{array}{c}6 \\
(0-600)\end{array}$ & $\begin{array}{c}1 \\
(0-5)\end{array}$ \\
\hline \multicolumn{8}{|c|}{ The four main groups } \\
\hline $\mathbf{L E}$ & $\begin{array}{l}23 \\
(6)\end{array}$ & $27 \%$ & $\begin{array}{c}41 \\
(23-66)\end{array}$ & $\begin{array}{c}0.6 \\
(0.0-5.6)\end{array}$ & $5 / 5 / 13$ & $\begin{array}{c}10 \\
(0-600)\end{array}$ & $\begin{array}{c}1 \\
(0-5)\end{array}$ \\
\hline HS & $\begin{array}{l}18 \\
(8)\end{array}$ & $21 \%$ & $\begin{array}{c}38 \\
(21-79)\end{array}$ & $\begin{array}{c}2.4 \\
(0.6-6.0)\end{array}$ & $8 / 6 / 4$ & $\begin{array}{c}6 \\
(0-150)\end{array}$ & $\begin{array}{c}2 \\
(0-3)\end{array}$ \\
\hline $\begin{array}{c}\text { Tumors } \\
\mathbf{I}^{\circ} / \mathbf{I I}^{\circ}\end{array}$ & $\begin{array}{l}12 \\
(4)\end{array}$ & $14 \%$ & $\begin{array}{c}32 \\
(20-44)\end{array}$ & $\begin{array}{c}3.0 \\
(0.0-6.0)\end{array}$ & $3 / 9 / 0$ & $\begin{array}{c}10 \\
(3-140)\end{array}$ & $\begin{array}{c}2 \\
(1-4)\end{array}$ \\
\hline $\begin{array}{c}\text { Amygdala } \\
\text { lesion }\end{array}$ & $\begin{array}{l}11 \\
(5)\end{array}$ & $13 \%$ & $\begin{array}{c}52 \\
(23-71)\end{array}$ & $\begin{array}{c}1.0 \\
(0.0-4.2)\end{array}$ & $2 / 8 / 1$ & $\begin{array}{c}4 \\
(1-100)\end{array}$ & $\begin{array}{c}1 \\
(0-1)\end{array}$ \\
\hline $\begin{array}{c}\text { Group } \\
\text { differences: } \\
P\end{array}$ & $\begin{array}{c}\text { Gender: } \\
\text { n.s. } *\end{array}$ & & $0.008 * *$ & $0.011 * *$ & $\begin{array}{l}\text { Bilate- } \\
\text { rality: } \\
<0.001 *\end{array}$ & n.s. ** & $0.01 * *$ \\
\hline \multicolumn{8}{|c|}{ Other diagnoses } \\
\hline Other & $\begin{array}{l}20 \\
(5)\end{array}$ & $24 \%$ & $\begin{array}{c}44 \\
(28-60)\end{array}$ & $\begin{array}{c}2.0 \\
(0.6-5.7)\end{array}$ & $7 / 7 / 6$ & $\begin{array}{c}14 \\
(1-450)\end{array}$ & $\begin{array}{c}1 \\
(0-3)\end{array}$ \\
\hline
\end{tabular}

AEDs=antiepileptic drugs; HS= hippocampal sclerosis (not related to LE); LE=limbic encephalitis; n.s. $=$ not significant. ${ }^{*} \mathrm{Chi}^{2}$ test. ${ }^{*} *$ Kruskal-Wallis-test. 


\section{Clinical features:}

Recent onset ( $\leq 5$ years) limbic syndrome in adult life defined by $\geq 1$ of the following 3 signs:

- Temporal lobe seizures

- Disturbance of recent memory

- Affective disturbance

plus

\section{Brain MRI:}

Otherwise unexplained mediotemporal FLAIR/T2 signal increase

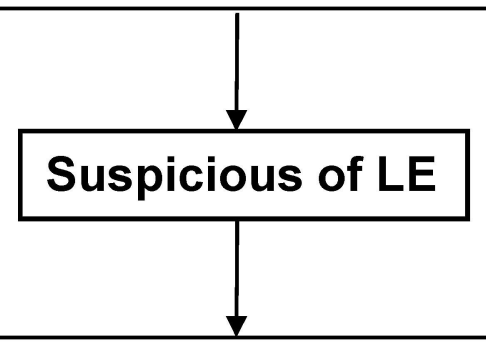

\section{$\geq 1$ of the following 3 criteria fulfilled?}

- Neuropathology: chronic mediotemporal encephalitis

- Evidence of tumor within 5 years of onset of neurological features

- "Well characterized" onconeural antibodies (according to Graus et al. 2004: anti-Hu, Ma/Ta-, CV2/CRMP5-, amphiphysin) or VGKC antibodies

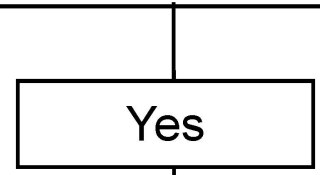

\section{MRI evolution?}

From signal increase and swelling to atrophy

\section{Definite LE}



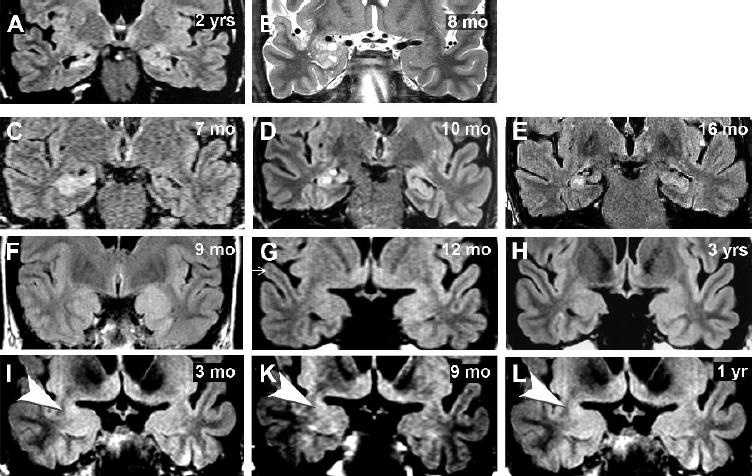